\title{
Tumor Necrosis Factor Alpha-induced Apoptosis in Cardiac Myocytes Involvement of the Sphingolipid Signaling Cascade in Cardiac Cell Death
}

\author{
Kevin A. Krown, ${ }^{\star}$ M. Trevor Page, ${ }^{*}$ Cuong Nguyen, ${ }^{*}$ Dietmar Zechner, ${ }^{\star}$ Veronica Gutierrez, ${ }^{\star}$ Kevyn L. Comstock, \\ Christopher C. Glembotski, ${ }^{\ddagger}$ Penelope J.E. Quintana, ${ }^{\star}$ and Roger A. Sabbadini* \\ *Department of Biology and ${ }^{\ddagger}$ Graduate School of Public Health, San Diego State University, San Diego, California 92182
}

\begin{abstract}
In the present study, it was shown that physiologically relevant levels of the proinflammatory cytokine TNF $\alpha$ induced apoptosis in rat cardiomyocytes in vitro, as quantified by single cell microgel electrophoresis of nuclei ("cardiac comets") as well as by morphological and biochemical criteria. It was also shown that $\mathrm{TNF} \alpha$ stimulated production of the endogenous second messenger, sphingosine, suggesting sphingolipid involvement in TNF $\alpha$-mediated cardiomyocyte apoptosis. Consistent with this hypothesis, sphingosine strongly induced cardiomyocyte apoptosis. The ability of the appropriate stimulus to drive cardiomyocytes into apoptosis indicated that these cells were primed for apoptosis and were susceptible to clinically relevant apoptotic triggers, such as $\mathrm{TNF} \alpha$. These findings suggest that the elevated $\mathrm{TNF} \alpha$ levels seen in a variety of clinical conditions, including sepsis and ischemic myocardial disorders, may contribute to $\mathrm{TNF} \alpha$-induced cardiac cell death. Cardiomyocyte apoptosis is also discussed in terms of its potential beneficial role in limiting the area of cardiac cell involvement as a consequence of myocardial infarction, viral infection, and primary cardiac tumors. (J. Clin. Invest. 1996. 98:2854-2865) Key words: apoptosis • cardiomyocytes - tumor necrosis factor $\cdot$ sphingosine $\bullet$ comet assay
\end{abstract}

\section{Introduction}

Apoptosis is a mechanism by which cells respond to damage by triggering a program of cell death (1-4). Apoptosis has only recently been recognized as a component of many common cardiac pathologies, including chronic heart failure, cardiac sudden death, viral myocarditis, and ischemia (5-13). Since the triggers and cellular mechanisms leading to cardiac cell apoptosis are not known, an understanding of this recently discovered form of cardiac cell death may help elucidate many common types of heart disease.

Serum levels of $\mathrm{TNF} \alpha$ are elevated in many human cardiacrelated pathogenic conditions, including heart failure (14-17).

Portions of this work have appeared in abstract form (1996. Biophys. J. 70:A280; and 1996. Basic and Appl. Myol. 6:307).

Address correspondence to Roger A. Sabbadini, Department of Biology and Molecular Biology Institute, San Diego State University, 5300 Campanile Dr., San Diego, CA 92182. Phone: 619-594-6272; FAX: 619-594-5676; E-mail: rsabba@sunstroke.sdsu.edu

Received for publication 25 June 1996 and accepted in revised form 30 September 1996.

J. Clin. Invest.

(C) The American Society for Clinical Investigation, Inc.

0021-9738/96/12/2854/12 \$2.00

Volume 98, Number 12, December 1996, 2854-2865
Because TNF $\alpha$ can trigger apoptosis in many cell types (18-20), it is possible that endogenous $\mathrm{TNF} \alpha$ may contribute to apoptosis in cardiac cells. Since TNF $\alpha$ may be produced by cardiac cells themselves $(21,22)$, it is possible that local concentrations of TNF $\alpha$ are high in cardiac tissue relative to serum levels. Significantly, we and others have shown that TNF $\alpha$ receptors are expressed by cardiomyocytes $(23,24)$. The "death domain" of the prominent type I receptor (TNFRI) ${ }^{1}$ present in cardiomyocytes has been linked to TNF $\alpha$-mediated apoptosis in nonmuscle cells (25), suggesting that TNF $\alpha$ acting via the TNFRI could also mediate myocardial cell apoptosis. Since the sphingomyelin signal transduction system has been linked to the TNFRI in other cell types (26), we hypothesize that many of the actions of $\mathrm{TNF} \alpha$ on cardiac cells, including apoptosis, could be mediated by $\mathrm{TNF} \alpha$-induced sphingolipid production.

We have taken the approach of using several techniques in parallel to evaluate apoptosis in cardiomyocytes in vitro, following treatment with TNF $\alpha$ and sphingolipids. These techniques include the in situ $3^{\prime}$ nick-end labeling (TUNEL) assay, the "laddering" of extracted DNA after agarose gel electrophoresis, as well as morphological criteria. In addition, we have employed the microgel electrophoresis method (27) (often referred to as the "comet assay") $(28,29)$, which is a relatively new technique for distinguishing apoptosis from necrosis. This technique can detect DNA damage earlier than other methods, and it can differentiate single from double-strand breaks and thus be specific for apoptosis (29-31). Moreover, the comet assay lends itself to the examination of a large number of cells. As a result of its utility, the comet assay has been employed by a number of laboratories to assess apoptosis in several cell types $(27,28,32-36)$. This broad range of criteria to assess apoptosis in cultured rat cardiomyocytes has been used in this study to determine whether cardiomyocyte death triggered by $\mathrm{TNF} \alpha$ and sphingolipids results from apoptosis or necrosis.

\section{Methods}

Neonatal rat ventricular cardiomyocytes were isolated as described previously and cultured in DMEM-F12/10\% FCS (37). Adult ventricular myocardial cells were cultured after dissociation from adult rat hearts as previously described (38), with the following modification: after the last perfusion with collagenase (type II; Worthington Biochemicals Corp., Freehold, NJ), rat ventricles were diced and incubated for 30 additional $\mathrm{min}$ at $37^{\circ} \mathrm{C}$ in $10-15 \mathrm{ml}$ of $0.52 \mathrm{mg} / \mathrm{ml}$ collagenase in oxygenated Tyrode's solution $(140 \mathrm{mmol} / \mathrm{liter} \mathrm{NaCl}$, $5.4 \mathrm{mmol} /$ liter KCl, $5.0 \mathrm{mmol} /$ liter $\mathrm{MgCl}_{2}, 10 \mathrm{mmol} /$ liter Hepes, 0.25 $\mathrm{mmol} /$ liter $\mathrm{NaH}_{2} \mathrm{PO}_{4}, \mathrm{pH}$ 7.3) in which the $\mathrm{CaCl}_{2}$ concentration had been adjusted to $0.06 \mathrm{mmol} / \mathrm{liter}$, before culturing cells in the physiological calcium levels present in the culture and incubation media (1.0

1. Abbreviations used in this paper: TNFRI, tumor necrosis factor type I receptor; TUNEL, TdT-mediated dUTP nick end labeling. 
$\mathrm{mmol} /$ liter $\mathrm{CaCl}_{2}$ ). The acutely dissociated myocardial cells were plated on laminin-coated $(50 \mu \mathrm{g} / \mathrm{ml})$ frosted microscope slides or on coverslips and culture in DMEM-F12/10\% FCS in the presence or absence of the test agent. These procedures result in a high percentage of viable cells, since necrotic cells supercontract in the presence of high calcium concentrations and do not adhere well to the substrate.

Apoptosis in cardiomyocytes was quantified by the single-cell microgel electrophoresis (comet assay) $(27,28,36,39)$. The comet assay is a method of measuring DNA strand breaks and has been used to quantify apoptotic cells from other tissues (31). In comparison with other methods of detecting apoptosis, the comet assay is considered more sensitive and able to detect DNA cleavage earlier than other methods $(29,30)$. The comet assay was performed essentially as described (39) with the following modifications: cells were cultured on frosted microscope slides, treated with the test agent (e.g., TNF $\alpha$, sphingosine, $\mathrm{H}_{2} \mathrm{O}_{2}$, ceramide, anti-TNFRI $\mathrm{Ab}$ ), and then embedded in situ in 1\% agarose (SeaKem Gold; FMC Bioproducts, Rockland, $\mathrm{ME})$. Cardiomyocytes were then placed in refrigerated alkaline lysis buffer (2.5 M NaCl, 1\% Na-lauryl sarcosinate, $100 \mathrm{mM}$ EDTA, $10 \mathrm{mM}$ Tris base, $1 \%$ peroxide, and carbonyl-free Triton X-100) for $30 \mathrm{~min}$, followed by 15 min unwinding in electrophoresis buffer containing $300 \mathrm{mM} \mathrm{NaOH}, 10 \mathrm{mM}$ EDTA, $0.1 \%$ hydroxyquinoline, $0.02 \%$ DMSO, $\mathrm{pH}$ 10.0. The nuclei were subsequently electrophoresed for $5 \mathrm{~min}$ at $2 \mathrm{~V} / \mathrm{cm}$, followed by staining with YOYO-1 ( $3 \mu \mathrm{mol} / \mathrm{liter}$; Molecular Probes, Inc., Eugene, OR) and visualization with a fluorescence microscope equipped with an FITC filter cube (Olympus Corp., Lake Success, NY). For quantification and image analysis of comet fields, fluorescent images of the nuclei were captured by a PULNIX TN-745 CCD camera connected to an Olympus BA-2 fluorescence microscope and digitally processed by KOMET software (Kinetic Imaging, Ltd., Liverpool, UK). Between 450 and 500 comets per treatment were scored and assigned into type A, B, or C categories (see Results), based on their tail moments (Table I). The tail moment is defined as the product of the comet tail length (distance between the mean of DNA fluorescence for the comet head and the end of the tail) and the proportion of DNA in tail (proportion of total fluorescence found in the tail region) divided by 100 (30). The tail moment parameter has been used to distinguish nucleosomal DNA fragmentation of apoptotic cells from DNA damage of those undergoing necrosis, and is a better discriminator than assessing comet tail length (36). According to Olive et al. (30), classification of individual cells into the various types of comets (e.g., B vs. C) "by eye" is the most accurate means of analyzing and quantifying large numbers of apoptotic cells. This was substantiated in the present study by experiments in which the percentage of apoptotic nuclei (type $\mathrm{C}$ comets) scored by eye were compared with the same data quantified by image analysis

\section{Table I. Categorization of Nuclei by Tail Moment (TM)}

\begin{tabular}{llc}
\hline & Mean TM $(\mu \mathrm{m})$ & TM range $(\mu \mathrm{m})$ \\
\hline Type A nuclei $(n=49)$ & $0.47 \pm 0.10$ & $0-3$ \\
Type B comets $(n=36)$ & $5.43 \pm 0.26^{*}$ & $3-8$ \\
Type C comets $(n=48)$ & $13.6 \pm 0.59^{*}$ & $8-30$
\end{tabular}

Tail moments \pm SEM were calculated from computerized image analyses using the KOMET software. The tail moment is defined as the product of the comet tail length (distance between the mean of DNA fluorescence for the comet head and end of the tail) and the proportion of DNA in the tail (proportion of total fluorescence) divided by 100. Data were taken from a set of experiments in which adult rat cardiomyocytes were treated with $\mathrm{TNF} \alpha$ to generate type $\mathrm{B}$ and $\mathrm{C}$ comets. Type A nuclei used for this analysis came from control (untreated) cells and from $\mathrm{TNF} \alpha$-treated nuclei displaying tail moments in the $0-3-\mu \mathrm{m}$ range. * Significant differences $(P<0.001)$ from mean type A tail moment as determined by ANOVA. using the criteria of tail moment (see Table II in Results). Consequently, in many experiments, even though tail moments were calculated for numerous control and treated nuclei in the A, B, and C categories, the number of apoptotic cells in a particular experiment was commonly assessed by counting the number of nuclei exhibiting puffy tail type comets with pinhead nuclear remnants (type $\mathrm{C}$ comets, e.g., Fig. $3 C$ ). Statistical analyses employed the Student's $t$ test, MantelHaenszel Chi Square trend analysis, and ANOVA using Microsoft Excel and SPSS software.

In addition to the comet assay, double-stranded DNA breaks were assessed by agarose gel electrophoresis of extracted cellular DNA and the presence of characteristic 180-200-bp multiple oligonucleosomal fragmentation (40).

Terminal deoxynucleotidyl transfer-mediated end labeling of fragmented nuclei (TUNEL assay) was performed on cardiomyocytes that had been plated on laminin-coated coverslips and cultured in DMEM-F12/10\% FCS in the presence or absence of the test agent. The in situ TUNEL assay was then performed in accordance with the manufacturer's protocol for cultured cells (Boehringer Mannheim Biochemicals, Indianapolis, IN) after fixing the cells in $4 \%$ paraformaldehyde for 30-60 min.

Morphological identification of apoptotic nuclei was assessed either by hematoxylin or ethidium bromide staining. For hematoxylin staining, cells were first treated with cold acetone $\left(-20^{\circ} \mathrm{C}\right)$, rinsed in cold PBS, and then stained for $20 \mathrm{~min}$. For ethidium bromide staining, cultured cells were fixed in $4 \%$ paraformaldehyde, treated with RNAse $\mathrm{A}(0.1 \%)$ at $37^{\circ} \mathrm{C}$ for $30 \mathrm{~min}$, followed by ethidium bromide treatment $(50 \mu \mathrm{g} / \mathrm{ml}$ for $15 \mathrm{~min})$. Ethidium bromide-stained cells were viewed by fluorescence microscopy using a rhodamine filter cube.

HPLC analysis of TNF $\alpha$-induced sphingolipid production by rat cardiac membranes was performed essentially as described previously (41). Cardiac membranes were isolated from adult rat ventricles as described (23). Freshly isolated membranes were incubated for 90 min in the absence (control) or presence of TNF $\alpha$. The membranes were then extracted for sphingolipids and processed for HPLC separation and quantification as previously described (41).

Reverse transcriptase PCR of TNFRI in adult and neonatal rat ventricular cells was performed essentially as described previously by us (23). Briefly, DNAse-treated poly $(\mathrm{A}+)$ RNA obtained from total RNA was reverse transcribed and the resultant cDNA amplified (30 cycles) by PCR using a programmable thermal cycler (PTC-100; MJ Research, Watertown, MA). Sense and antisense primers for rat TNFRI were 5'-GCTCCTGGCTCTGCTGAT-3' and 5'-AACATTTCTTTCCGACAT-3', respectively. Primers for atrial natriuretic factor, 5'-AGCGGGGGCGGCACTTAG-3' (sense), and 5'-CTCCAATCCTGTCAATCC-3' were included as a positive control for myocardial gene expression. Primers were synthesized in the San Diego State University Microchemical Core Facility. The reverse transcriptase PCR product was separated on a $2 \%$ agarose gel. The sizes of the amplification products for rat TNFRI and atrial natriuretic factor were 288 and $212 \mathrm{bp}$, respectively.

\section{Results}

We hypothesize that $\mathrm{TNF} \alpha$ and sphingolipids are capable of driving rat cardiomyocytes into apoptosis. We present results from in vitro studies using cultured cardiomyocytes exposed to $\mathrm{TNF} \alpha$ and to the lipid second messengers, sphingosine, sphingosine-1-phosphate, and ceramide. To assess apoptosis in cardiomyocytes, we employed a multiplicity of techniques, including single-cell microgel electrophoresis (comet assay), the in situ TUNEL assay, and laddering of extracted DNA after agarose gel electrophoresis in addition to conventional cytological methods. Trypan blue exclusion and other criteria were also used to determine if cardiomyocytes succumb by necrosis 

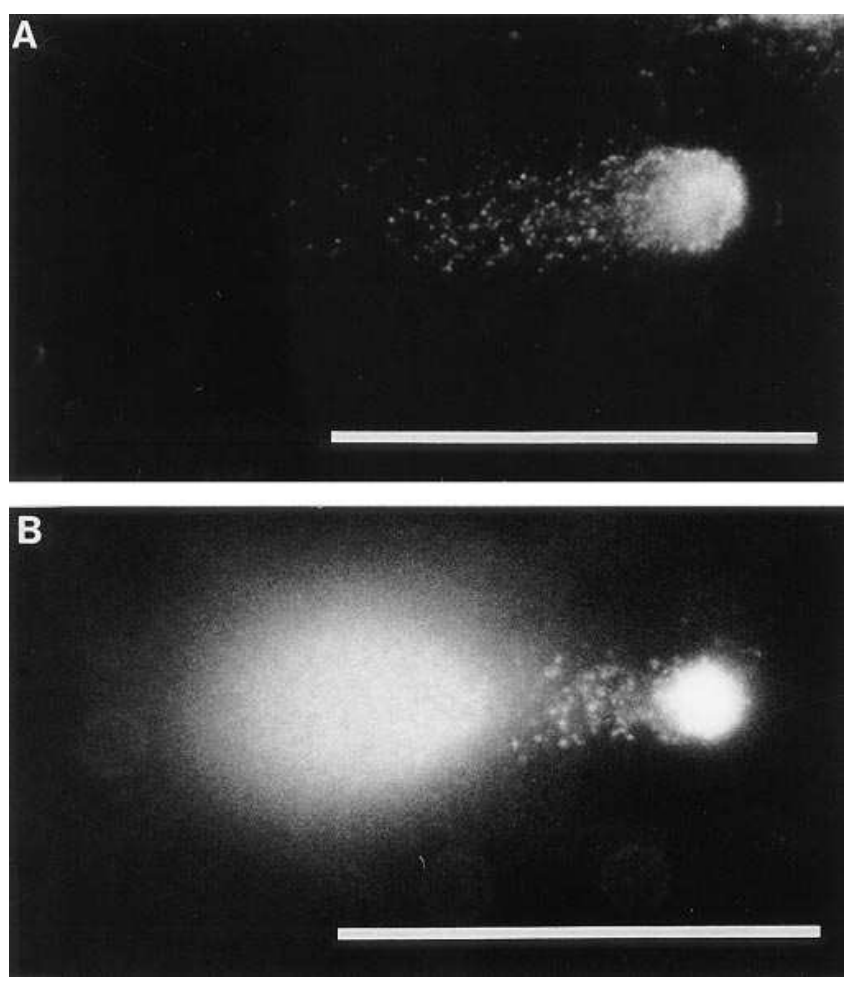

Figure 1. Single cell microgel electrophoresis (the comet assay) can distinguish single-stranded from double-stranded DNA fragmentation in rat cardiomyocytes. Adult cardiomyocytes were treated for 20 min with $100 \mu \mathrm{mol} /$ liter $\mathrm{H}_{2} \mathrm{O}_{2}$ to induce necrosis $(A)$ or with $10 \mu \mathrm{mol} /$ liter $\mathrm{C} 2$ ceramide $(18 \mathrm{~h})$ to induce apoptosis $(B)$, and then were subjected to the comet assay. Nuclei were visualized by YOYO-1 staining under fluorescence microscopy. The comets displayed in both $A$ and $B$ were not digitally enhanced. Bar represents $50 \mu \mathrm{m}$.

rather than by the apoptotic process when subjected to TNF $\alpha$ and sphingolipid triggers. Hydrogen peroxide was employed as a positive control for induction of single strand breaks.

Assessment of apoptosis in cardiomyocytes using single-cell microgel electrophoresis (the comet assay). The sphingolipid, ceramide, was chosen for our initial evaluation of sphingolipidinduced apoptosis in cardiac myocytes since ceramide is a well established inducer of apoptosis in nonmuscle cells and is thought to be a significant second messenger mediating apoptosis triggered by cytokines such as TNF $\alpha$ and by other agents (42). To measure apoptosis in cardiomyocytes, a very sensitive and relatively new method, the comet assay, was used in these studies. The comet assay has been employed by many laboratories as a sensitive method of assessing DNA fragmentation $(27,28,32-36)$, but has not been applied to cardiomyocyte cell death. In this report, the comet assay was used to evaluate apoptosis in both adult and neonatal rat cardiomyocytes. Cultured cardiomyocytes were embedded in agarose, lysed, and electrophoresed (see Methods). As a result of conditions that promote unwinding, DNA fragments are free to migrate in the agarose away from the nucleus forming an image that resembles a comet tail (Fig. 1). The pattern of DNA fragmentation detected by the comet assay has been used to distinguish the double-stranded DNA cleavage commonly accompanying apoptosis from the random breaks often seen in necrosis or produced by genotoxic agents (29-31). To compare putative apoptosis produced by sphingolipids to genotoxic/necrotic damage, we incubated cardiomyocytes for 20 min with 100 $\mu \mathrm{mol} /$ liter $\mathrm{H}_{2} \mathrm{O}_{2}$, a treatment that is often used to induce random single-strand DNA breaks $(36,43)$ (Fig. $1 A$ ). This treatment produced comets with small tails, with most of the DNA unfragmented and remaining in the nucleus. Incubation of cardiomyocytes with the sphingolipid $\mathrm{C} 2$ ceramide produced a distinct comet pattern characterized by a puffy comet tail disconnected from the remnant nucleus (Fig. $1 B$ ), a pattern of DNA fragmentation that is characteristic of apoptosis exhibited by other cell types and has been attributed to doublestrand breaks (29-31).

Fig. $2 A$ shows a field of control (untreated) myocardial cells and Fig. $2 B$ shows a field of $\mathrm{C} 2$ ceramide-treated cells, demonstrating that the comet assay can be used to evaluate the effects of apoptotic-inducing agents on large numbers of cells. One can readily see from the density of nuclei in Fig. $2 \mathrm{~A}$ vs. $2 B$ that approximately the same number of cells survived the ceramide treatment and thus direct quantitative comparisons can be made between treatment conditions. Nuclei from untreated, non-apoptotic cells (Fig. $2 A$ ) appeared as spheroids after electrophoresis. On the other hand, fields of $\mathrm{C} 2$ ceramide-treated cells displayed a full range of comet types (Fig. 2 B). The amount and type of DNA damage in each nucleus was assessed by image analysis and "by eye," as discussed in Methods. Nuclei from untreated, nonapoptotic cells had no tails and consequently most cells displayed negligible tail moments (mean $0.47 \mu \mathrm{m}$ in these experiments). Electrophoresed nuclei classified by us as type A nuclei displayed little damage and had tail moments in the range of $0-3 \mu \mathrm{m}$ (Fig. $3 A$ and Table I). The nuclei resembling comets resulting from ceramide or other apoptosis inducers (see below) were of two general types that could be distinguished visually and quantitatively by their tail moments and are referred to as types B and C comets. Type B comets were those nuclei that had a developing tail but with a substantial amount of unfragmented DNA present in the "head" of the comet (mean tail moments of $5.43 \mathrm{~mm}$, range $3-8 \mu \mathrm{m}$, Fig. $3 B$ and Table I). Type C comets were those nuclei with the apoptotic-associated pattern previously observed (29-31), a characteristic puffy tail separated by a space from the pinhead remnant of the head (e.g., Fig. $3 C$ ), and having tail moments in the $8-30 \mu \mathrm{m}$ range with mean values of $13.6 \mu \mathrm{m}$ (Table I). Table I gives a comparison of image analysis-derived tail moment measurements in our system for types $\mathrm{A}, \mathrm{B}$, and $\mathrm{C}$ nuclei.

Based on this data, we concluded that, with the extensive amount of DNA fragmentation observed in our studies after treatment of cardiac myocytes with $\mathrm{C} 2$ ceramide (Fig. $3 \mathrm{D}$ ), use of the comet assay was a rapid and effective method of evaluating apoptosis. Moreover, this first demonstration of ceramide-triggered apoptosis in cardiomyocytes suggested that the heart might be susceptible to other well characterized apoptotic triggers, such as TNF $\alpha$ or other cytokines.

$T N F \alpha$ induces apoptosis but not necrosis in adult rat cardiomyocytes. When primary rat cardiomyocytes were analyzed by the comet assay after an 18-h incubation with $4 \mathrm{nmol} / \mathrm{liter}$ $\mathrm{TNF} \alpha$ (recombinant rat $\mathrm{TNF} \alpha$ from Biosource, Camarillo, CA), substantial apoptosis was evident (Fig. $3 \mathrm{D}$ ). For control (untreated) cells, nearly $80 \%$ of the nuclei appeared as spheroids, categorized as type A (Fig. $3 \mathrm{D}$ ). In contrast, over $60 \%$ of nuclei in TNF $\alpha$-treated cells yielded comets typical of apoptosis (type C) with pinhead nuclear remnants, and puffy tails 

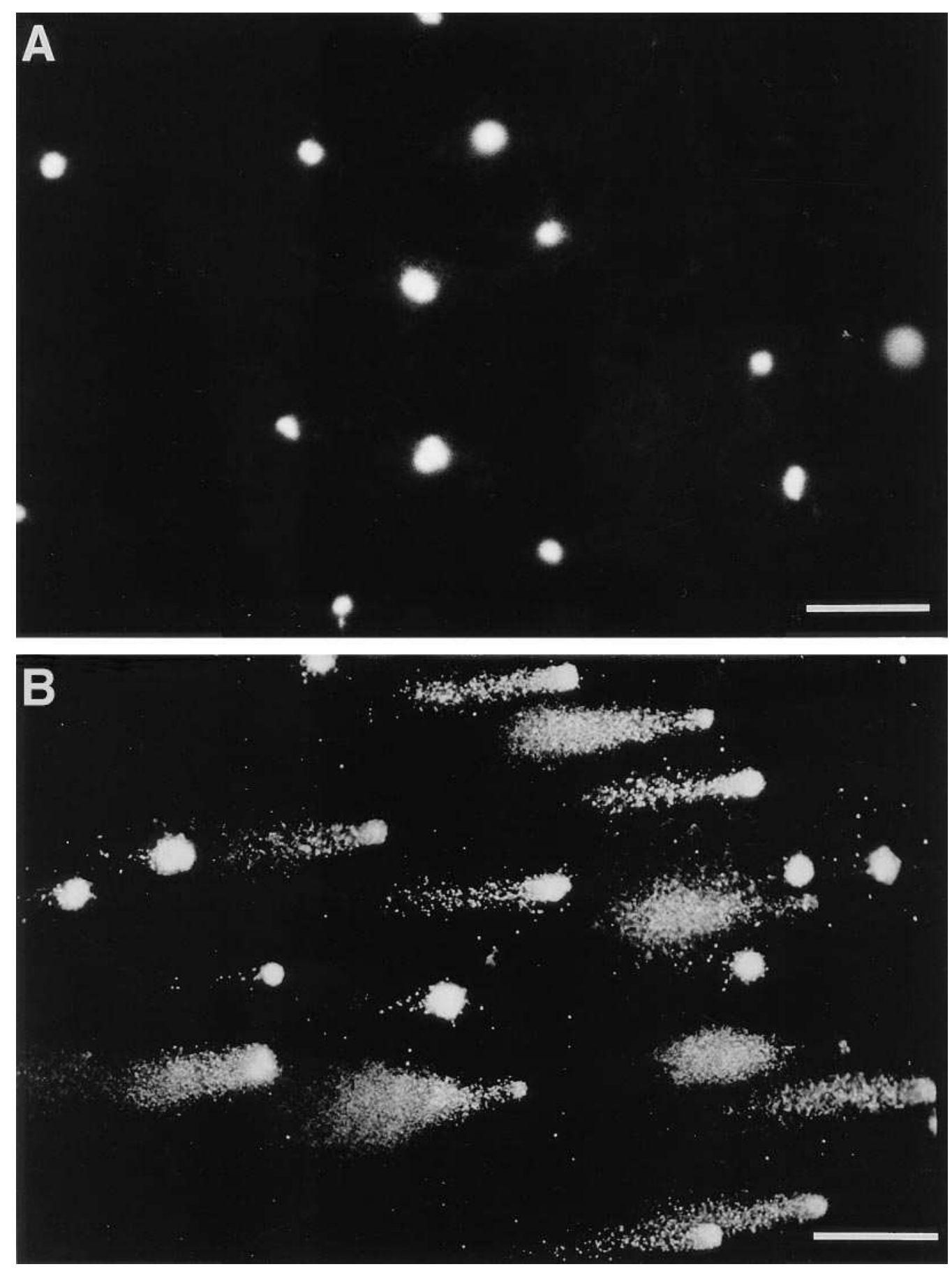

Figure 2. Ceramide drives large numbers of rat cardiomyocytes into apoptosis. Nuclei of adult cardiomyocytes were electrophoresed according to the comet procedure (see Methods). Cells were either untreated for $18 \mathrm{~h}(A)$ or incubated for $18 \mathrm{~h}$ with $10 \mu \mathrm{mol} /$ liter $\mathrm{C} 2$ ceramide $(B)$ before cell lysis and electrophoresis of nuclei. Nuclei were visualized by YOYO-1 and digitally enhanced (see Methods). Bar represents $50 \mu \mathrm{m}$.

and tail moments in the $8-30 \mu \mathrm{m}$ range. The cardiomyocyte DNA fragmentation pattern we observed was likely due in large part to double-strand DNA breaks typical of apoptosis, since extensive comet formation was observed using the double-strand break-specific neutral comet assay (30) (data not shown). The percentage of type $\mathrm{C}$ comets was linearly depen- dent on the concentration of TNF $\alpha$ in the $1-4 \mathrm{nmol} /$ liter range (Fig. 4), reaching a maximum effect (61\% apoptotic cells) at $4 \mathrm{nmol} /$ liter TNF $\alpha(3,500 \mathrm{U} / \mathrm{ml}, 68 \mathrm{pg} / \mathrm{ml})$, and then declining somewhat at $5 \mathrm{nmol} / \mathrm{liter}(4,250 \mathrm{U} / \mathrm{ml}, 85 \mathrm{pg} / \mathrm{ml})$. The halfmaximal concentration of $\mathrm{TNF} \alpha$ required to induce apoptosis in our cardiomyocytes was $2.2 \mathrm{nmol} / \mathrm{liter}(1,870 \mathrm{U} / \mathrm{ml}, 37.4$

Figure 3. TNF $\alpha$ and sphingolipids drive significant numbers of adult rat cardiomyocytes into apoptosis. Adult cardiomyocytes were treated for $18 \mathrm{~h}$ in culture with media alone (control), $4 \mathrm{nmol} /$ liter $(3,500 \mathrm{U} / \mathrm{ml}, 68 \mathrm{pg} / \mathrm{ml}) \mathrm{TNF} \alpha$ (recombinant rat TNF $\alpha), 10 \mu \mathrm{mol} /$ liter sphingosine $(S P H)$, or 10 $\mu \mathrm{mol} /$ liter $\mathrm{C} 2$ ceramide $(C 2)$, followed by the comet assay. $(A-C)$ Representative nuclei of the various categories, types A (nonapoptotic), B (intermediate and nonapoptotic DNA damage), and C (characteristic of apoptosis). (D) Cumulative results displayed as a bar graph. In $D$, values 

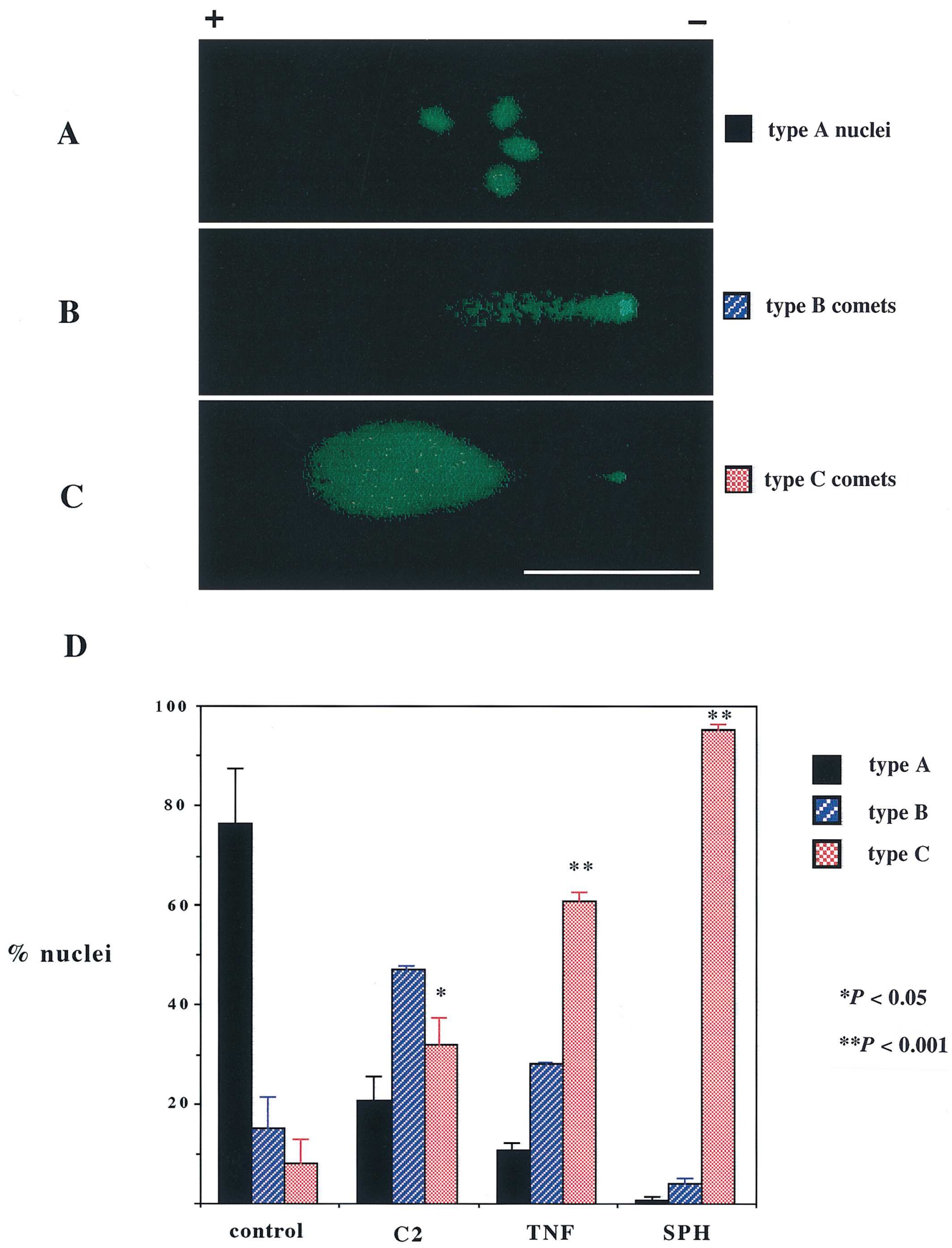

are means of three separate experiments $( \pm$ SEM) with each treatment performed on $>6,000$ cells. Between 450 and 500 comets per treatment point were scored and assigned into type A, B, or C categories. Bar represents $50 \mu \mathrm{m}$. 


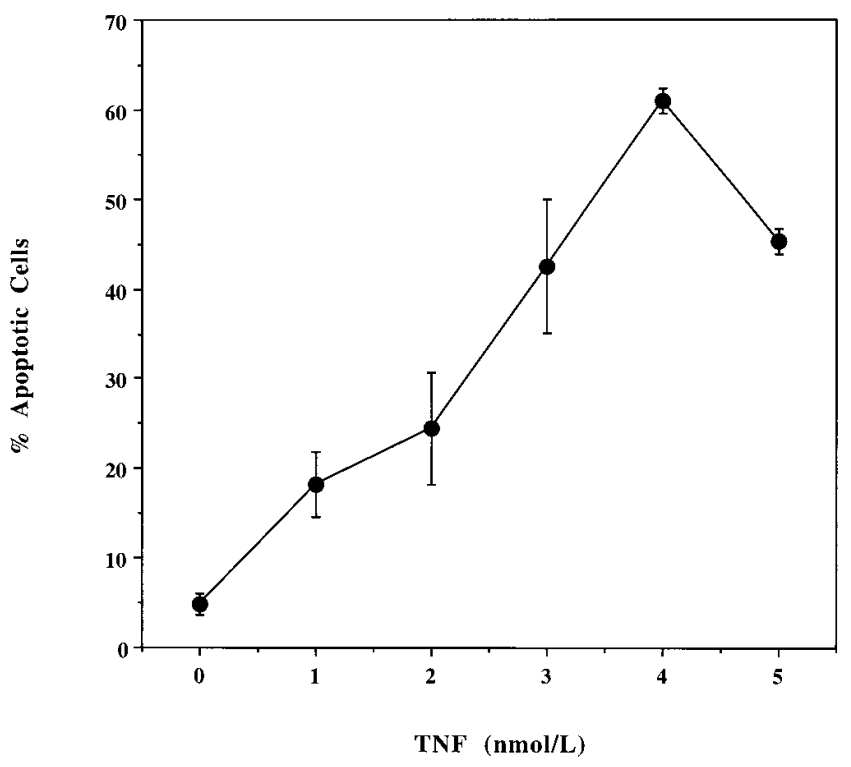

Figure 4. Dose dependence of TNF $\alpha$-induced apoptosis in adult cardiomyocytes. Adult rat cardiomyocytes were treated for $18 \mathrm{~h}$ with varying concentrations of TNF $\alpha$ as shown. The percentage of apoptotic-type (type C) nuclei is plotted as a function of TNF $\alpha$ concentration in nanomoles per liter. Results are means \pm SEM of 10,733 nuclei counted from four separate experiments. ANOVA and MantelHaenszel Chi Square trend analysis revealed a significant $(P<0.001)$ dose-dependent effect of TNF $\alpha$ in its ability to induce apoptosis.

$\mathrm{pg} / \mathrm{ml})$. The reason for the statistically significant $(P<0.001$, Students $t$ test) decline in the ability of TNF $\alpha$ to induce apoptosis at $5 \mathrm{nM} \mathrm{TNF} \alpha$ is unknown, but may result from downregulation of the receptor by receptor-mediated endocytosis, which would reduce cell responsiveness to TNF $\alpha$. The percentage of type $\mathrm{C}$ comets shown in Fig. 4 was determined by eye (see Methods), and comparison measurements of tail moment were made using a subset of the same cells. This comparison is displayed in Table II and shows that the percent apoptotic nuclei determined by characterizing the cells by eye was nearly identical to determinations characterizing the cells using the

Table II. Comparison of Percentage of Apoptotic Cells Determined by Image Analysis of Tail Moment (TM) vs. Visual Determination

\begin{tabular}{lcc}
\hline & \multicolumn{2}{c}{$\begin{array}{c}\text { Percent apoptotic cells (percent type C } \\
\text { comets) } \pm \text { SEM }\end{array}$} \\
\cline { 2 - 3 } TNF $\alpha$ concentration & By TM & By visual \\
\hline nmol/liter & & \\
1 & $20.6 \pm 9.01$ & $18.3 \pm 3.58$ \\
2 & $24.3 \pm 9.50$ & $24.4 \pm 6.24$ \\
3 & $27.8 \pm 16.3$ & $42.5 \pm 7.40$ \\
4 & $61.2 \pm 5.70$ & $61.0 \pm 1.45$ \\
\end{tabular}

The percentage of apoptotic cells (percent type C comets) scored by computerized image analysis of tail moment were compared with the percentage of apoptotic cells scored by visual inspection of individual cells (data taken from Fig. 4). The two methods of scoring comets were not significantly different ( $t$ test of differences, comparison of slopes).

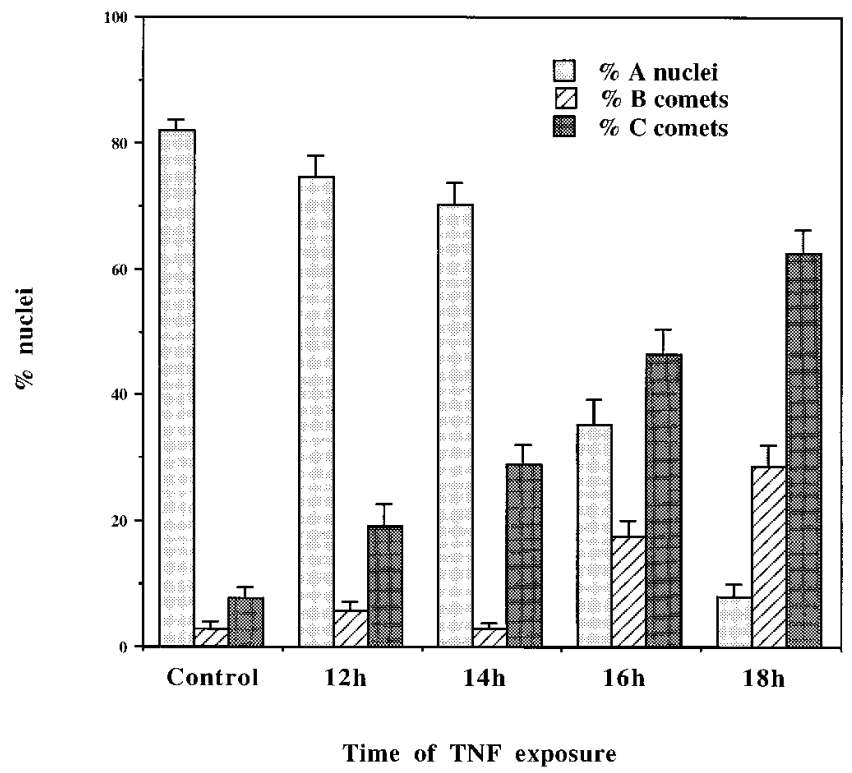

Figure 5. Time dependence of TNF $\alpha$-induced apoptosis in adult rat cardiomyocytes. Cultured adult cardiomyocytes were incubated with $4 \mathrm{nmol} /$ liter TNF $\alpha$ for various time periods as indicated. The percent apoptotic-type (type C) nuclei are plotted as a function of TNF $\alpha$ exposure, with the percentage of type A and B comets also listed. Results are means \pm SEM of 36 fields of cardiomyocyte nuclei. The percentage of type $\mathrm{C}$ comets significantly increased with time $(P<0.001$ ANOVA and Mantel-Haenszel Chi Square trend analysis) from control cells incubated with media alone for $18 \mathrm{~h}$.

tail moment calculated by computerized image analysis. Fig. 4 also shows that $\sim 5 \%$ of untreated cells in culture display apoptotic type comets. This basal level of apoptosis in control cell cultures likely results from the harsh manner in which cells are prepared for culture (i.e., collagenase treatment of Langendorff-perfused hearts). The data in Fig. 5 indicate that the extent of apoptosis produced by TNF $\alpha$ was dependent on the exposure time of cells to the cytokine. This figure shows that from 12 to $18 \mathrm{~h}, 4 \mathrm{nmol} /$ liter TNF $\alpha$ progressively drove an increasing number of cells into apoptosis as judged by the steady increase in type $\mathrm{C}$ comets and the concomitant decrease in type A undamaged nuclei. ANOVA performed on these data showed that there was a significant $(P<0.001)$ time-dependent effect of TNF $\alpha$ on the adult cardiomyocytes. Since $12 \mathrm{~h}$ of incubation was needed for TNF $\alpha$ to induce significant apoptosis $(P<0.001)$, it is likely that some protein synthesis was required to complete the death program.

To demonstrate that the TNF $\alpha$-induced apoptosis was mediated by the TNFRI, which we have recently identified as the prominent receptor subtype found on rat cardiomyocytes (23), we incubated adult rat cardiomyocytes overnight with $2.5 \mu \mathrm{g} / \mathrm{ml}$ anti-sTNFRI (mAb clone 16803.1 supplied by R \& D Systems Inc., Minneapolis, MN), and then subjected the cells to the comet assay. As seen by the data presented in Table III, the anti-TNF $\alpha$ receptor antibody, when added alone, was capable of driving a significant $(P<0.0001$, Student's $t$ test) number of adult cardiomyocytes into apoptosis $(51.9 \%)$. The extent of apoptosis produced by antibody interaction with the receptor was comparable with that produced by TNF $\alpha(47.6 \%)$, and no significant additive effect was seen when cells were incubated 
Table III. Effects of Anti-TNFRI Antibodies

Percent apoptotic nuclei

\begin{tabular}{lc}
\hline No treatment & $13.7 \pm 2.66$ \\
TNF $\alpha$ & $47.6 \pm 4.97 *$ \\
Anti-sTNFRI & $51.9 \pm 3.53^{*}$ \\
TNF $\alpha+$ anti-sTNFRI & $42.9 \pm 4.00^{*}$
\end{tabular}

Adult rat cardiomyocytes were incubated overnight with $\mathrm{TNF} \alpha,(3,500$ $\mathrm{U} / \mathrm{ml}$ ), $02.5 \mu \mathrm{g} / \mathrm{ml}$ anti-sTNFRI (mAb clone 16803), or a combination of both, and then subjected to the comet assay. Type $\mathrm{C}$ comets were taken as indicators of the percentage of apoptotic nuclei. 279 fields of comets from two separate experiments were scored for type $\mathrm{C}$ comets. Values are means \pm SEM. *Antibody produced significantly more $(P<0.0001$, Student's $t$ test) apoptotic comets than did control cells. No significant differences were seen among the three treatment groups. with $\mathrm{TNF} \alpha$ and the antibody in combination (42.9\% apoptotic cells).

Evidence for TNF $\alpha$-induced apoptosis demonstrated by the comet assay was further substantiated by in situ terminal deoxynucleotide transfer-mediated labeling of TNF $\alpha$-treated cardiomyocytes (Fig. $6 \mathrm{~A}$ ), although this method cannot distinguish random single- from double-strand DNA cleavage, as does the comet assay. In one experiment, we directly compared the TUNEL assay performed on a duplicate set of cultured cells processed for the comet assay after treatment with TNF $\alpha$. The TUNEL assay showed that $32.5 \%$ of the TNF $\alpha$-treated cells had strong enough fluorescent signals to be counted as apoptotic, compared with $>60 \%$ apoptotic nuclei determined by the comet assay using similar conditions of TNF $\alpha$ treatment (Fig. 3 $D)$. Thus, the TUNEL assay appears to be somewhat less sensitive than the comet in assessing apoptosis in cardiomyocytes.
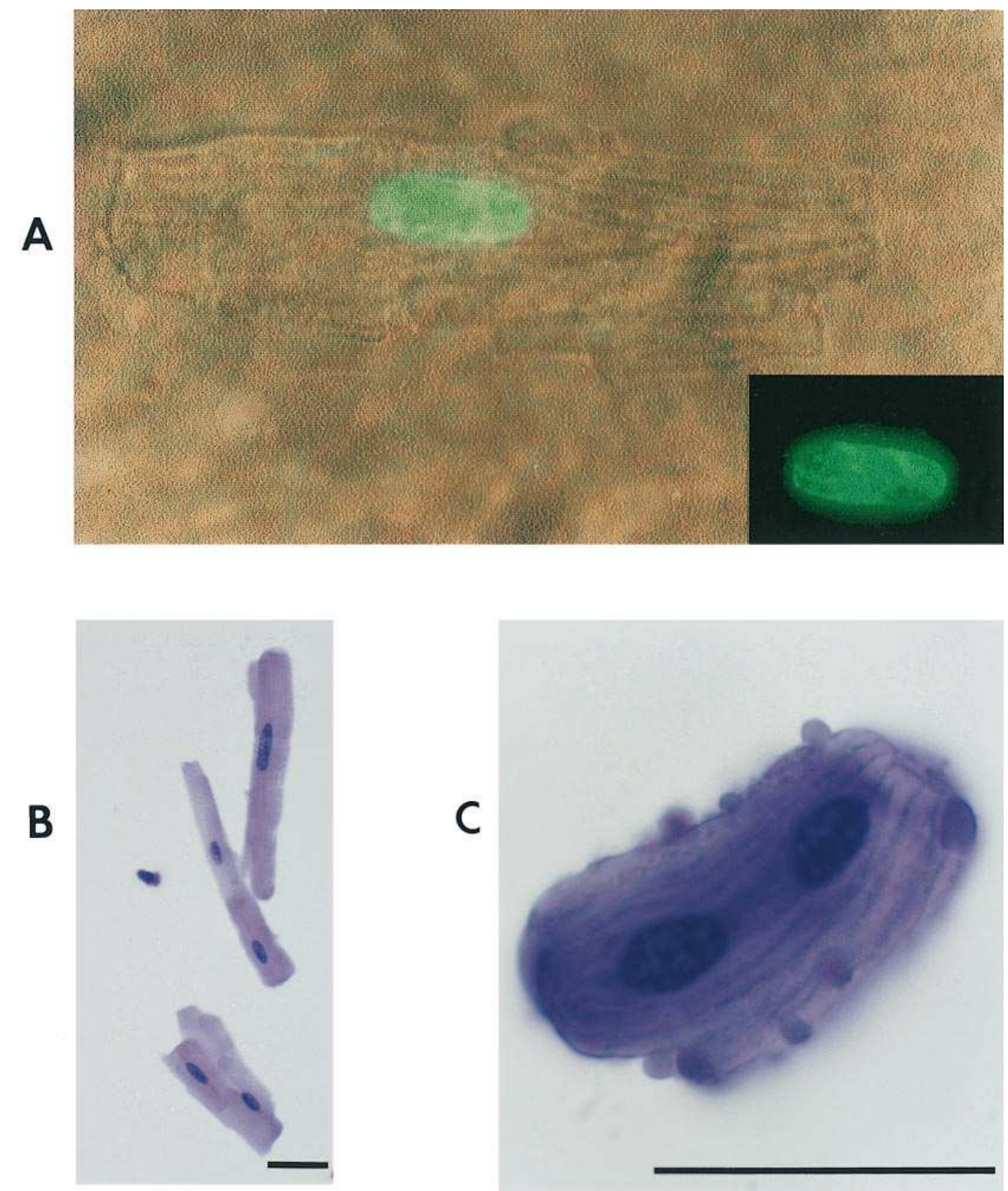

Figure 6. In situ morphological assessment of apoptosis in adult cardiomyocytes. $(A)$ An adult rat cardiomyocyte was treated with $300 \mathrm{U} / \mathrm{ml} \mathrm{TNF} \alpha$ followed by staining for DNA damage by in situ terminal deoxynucleotidyl transfer-mediated end labeling of fragmented nuclei (TUNEL assay). The myocyte was visualized under bright field illumination (to show the rodshaped outline of the cell) and under fluorescence (to visualize the damaged nucleus, which appears green). The inset is the fluorescent image (i.e., TUNEL) alone. Nonapoptotic cardiomyocytes have nuclei that do not fluoresce (data not shown). (B-C) Hematoxylin staining of adult cardiomyocytes cultured in the absence $(B)$ and presence $(C)$ of $10 \mu \mathrm{mol} / \mathrm{liter}$ sphingosine. The low magnification $(200 \times)$ image of untreated myocytes $(B)$ shows both mononucleated and binucleated cells that exhibit the typical rod shape and elongated nuclei, while the apoptotic cell seen in $C$ is somewhat crenated with prominent membrane blebbing and condensed chromatin in its nucleus. Bars represent $50 \mu \mathrm{m}$. 
An important feature of apoptosis that distinguishes apoptosis from necrosis is maintenance of plasma membrane integrity (1-3). Apoptotic adult cardiomyocytes such as those displayed in Fig. $6 \mathrm{~A}$ demonstrated substantial DNA fragmentation, but often retained their rod-shaped appearance indicative of intact plasma membranes. In this experiment, a TUNEL-positive cell was examined under bright field to confirm that DNA damage had occurred in a rod-shaped cell. The otherwise normal appearance of the cell not only confirmed that this cardiomyocyte underwent apoptosis while maintaining the integrity of its plasma membrane, but also suggested that the rod-shaped cardiomyocytes displaying apoptotic signs were not necrotic. Over $50 \%$ of such cells retained their rodshaped appearance and were not "supercontracted" in the presence of millimolar $\mathrm{Ca}^{2+}$, as would be the case for permeabilized necrotic cells. Supercontracture results from the cardiomyocyte's unique sensitivity to changes in plasmalemma $\mathrm{Ca}^{2+}$ permeability and can be used as an additional discriminator between apoptosis and necrosis. In the necrotic myocyte, characterized by loss of membrane integrity, the uncontrolled influx of $\mathrm{Ca}^{2+}$ down a steep electrochemical gradient results in supercontracture of the cell. The subsequent "balled-up" morphology and loss of defined cell structure can be clearly distinguished from the normal rod-shaped myocyte seen in Fig. $6 A$. Apoptotic cells such as the one displayed in Fig $6 A$ are not easily distinguished morphologically from untreated rodshaped cells such as the hemotoxylin and eosin-stained cells shown in Fig. 6 B. While rod-shaped apoptotic cells are common, occasionally apoptotic cells appear shrunken with evidence of membrane blebbing more characteristic of apoptotic cells from nonmuscle tissue (Fig. 6 C). A comparison of panels



Figure 7. Analysis of $\mathrm{TNF} \alpha$-induced sphingosine production by adult rat cardiac membranes. Membranes were incubated for $90 \mathrm{~min}$ in the absence (Control) or presence of $\mathrm{TNF} \alpha$, followed by extraction of sphingolipids and their separation by HPLC. Values are means (picomoles per milligram of cardiac membranes) \pm SEM of eight extractions performed on two separate membrane preparations. Data were analyzed by Student's $t$ test. *TNF $\alpha$ significantly $(P<0.005)$ stimulated sphingosine production.
$A, B$, and $C$ illustrates that apoptotic cardiomyocytes can appear either rod-shaped or crenated (also see Fig. 6, legend), and these morphological variations may reflect different stages of the apoptotic process. While the cell shown in Fig. $6 C$ was clearly apoptotic, as judged by the presence of membrane blebbing, this appearance was not a common feature of adult cardiomyocytes driven into apoptosis by $\mathrm{TNF} \alpha$ or other triggers, and likely represents a cell in an advanced stage of apoptosis. Additionally, cells such as this one were found to exclude trypan blue and to respond to $\mathrm{Ca}^{2+}$ ionophores, providing further evidence that they were not necrotic. In general, $>80 \%$ of cells induced into apoptosis were found to supercontract after challenge with the $\mathrm{Ca}^{2+}$ ionophore, A23187, suggesting that the cell membranes were intact and not permeable to $\mathrm{Ca}^{2+}$ before ionophore addition. As a further check of cell membrane integrity a subset of cell fields was examined for indo-1 fluorescence. Cells are permeable to indo- 1 AM, which is subsequently de-esterified in the cell to an impermeant $\mathrm{Ca}^{2+}$-sensitive species. Without exception, the same cells that excluded trypan blue and responded to the ionophore also retained and fluoresced the $\mathrm{Ca}^{2+}$-sensitive fluorescent dye, indo-1 AM.

$T N F \alpha$ activates the sphingomyelin signal transduction cascade. Because it has been demonstrated that $\mathrm{TNF} \alpha$ may produce apoptosis in a variety of cell types, principally through ceramide production $(18,19)$ or via ceramide's conversion product, sphingosine (20), it is possible that $\mathrm{TNF} \alpha$-mediated cardiac apoptosis may result from enhanced sphingolipid production. When cardiac membranes were exposed to $\mathrm{TNF} \alpha$, substantial (1.57-fold) sphingosine production was observed (Fig. 7), suggesting that this lipid may be an important mediator of the effects of TNF $\alpha$ in cardiac tissue. Consistent with this hypothesis, treatment of primary cardiomyocytes with sphingosine (10 $\mu \mathrm{mol} / \mathrm{liter})$ for $18 \mathrm{~h}$ resulted in characteristic apoptotictype comets in almost all $(95 \%)$ of the cardiomyocytes observed (Fig. 3 D). The cell permeant ceramide analog, C2 ceramide $(10 \mu \mathrm{mol} /$ liter $)$, was somewhat less effective in stimulating cardiomyocytes to undergo apoptosis, with only $32 \%$ apoptotictype comets produced (Fig. $3 \mathrm{D}$ ). Sphingosine also produced the characteristic morphological changes that are hallmarks of apoptosis, including nuclear condensation and membrane blebbing (Fig. $6 C$ ). In neonatal cardiomyocytes, sphingosine produced oligonucleosomal DNA laddering and prominent pyknotic nuclear fragmentation patterns characteristic of apoptosis (see below).

To confirm that the adult cardiomyocytes treated with sphingosine were not necrotic, trypan blue exclusion was employed as an indicator of plasma membrane permeability (Table IV). Over $80 \%$ of sphingosine-treated cells excluded trypan

Table IV. Percent Necrotic Cardiomyocytes

Control myocytes $(n=153)^{\ddagger}$

$21.0 \pm 1.27 *$

Sphingosine $18 \mathrm{~h}(n=162)$

$17.2 \pm 2.80$

Trypan blue $(0.1 \%)$ exclusion was one criterion used to identify necrotic cardiomyocytes. Values represent means \pm SEM of cells that did not exclude the dye and were considered necrotic. The remainder of the cells excluded trypan blue and were thus taken to be viable. See text for other tests used for necrosis (supercontraction when challenged with the $\mathrm{Ca}^{2+}$ ionophore, A23187, and retention and fluorescence of the $\mathrm{Ca}^{2+}$-sensitive fluorescent dye, indo-1 AM). *No significant difference as determined by Student's $t$ test. ${ }^{\ddagger} n=$ number of cells counted from four different fields of cells. 
blue after $18 \mathrm{~h}$ in culture. Since these same conditions caused more than $95 \%$ of the cells to become apoptotic as judged by the comet assay (Fig. $3 D$ ), sphingosine must induce apoptosis without appreciable signs of necrosis. This conclusion is supported by the finding that after sphingosine treatment, $50.5 \%$ of the apoptotic cells retained their rod-shaped appearance and did not supercontract in the presence of millimolar $\mathrm{Ca}^{2+}$.

Apoptosis in neonatal cardiomyocytes. Sphingolipids can also drive neonatal cardiomyocytes into apoptosis (Figs. 8 and 9). When cells were cultured for $18 \mathrm{~h}$ with $10 \mu \mathrm{mol} / \mathrm{liter} \mathrm{C} 2$ ceramide, sphingosine-1-phosphate, or sphingosine, the cells showed extensive DNA fragmentation with discernible $\sim 200$-bp oligonucleosomal laddering characteristic of apoptosis (Fig. 8). Control cells cultured in DMEM/F12 with $10 \%$ FCS did not show any discernible laddering or other features of apoptosis. In comparison with sphingosine, $\mathrm{C} 2$ ceramide was less effective in producing oligonucleosomal ladders. The lower effectiveness of ceramide in inducing neonatal cells into apoptosis is in agreement with the comet data of Fig. $3 \mathrm{D}$, showing that in adult cells, sphingosine produced a higher yield of apoptotic type cells than did ceramide. When neonatal cardiomyocytes were cultured overnight with sphingosine, $72.2 \pm 12.8 \%$ of the cells exhibited type $\mathrm{C}$ apoptotic-type comets (data from five fields of neonatal cells) compared with $0.0 \%$ type $\mathrm{C}$ comets exhibited by control (untreated) cells (data from four fields of neonatal cells). Treatment of neonatal cardiomyocytes with the sphingosine conversion product, sphingosine-1-phosphate, showed extensive oligonucleosomal DNA fragmentation, suggesting that this metabolite may be physiologically relevant in the signaling pathway for apoptosis in cardiomyocytes. Curiously, TNF $\alpha$ did not produce detectable apoptosis in neonatal cardiomyocytes as evidenced by absence of significant laddering, or by comet and TUNEL analyses (data not shown).

In agreement with the presence of double-stranded DNA cleavage on agarose gels, neonatal cells displayed TUNEL staining in response to sphingosine (Fig. 9). Untreated (control) cardiomyocytes were largely unstained (Fig. $9 A$ ), while most of the cells treated with sphingosine (Fig. $9 B$ ) were apoptotic as judged by nick-end labeling of fragmented DNA. Many of the nick-end-labeled nuclei in Fig. $9 \mathrm{~B}$ showed evidence of pyknotic bodies. Ethidium bromide-stained neonatal cardiomyocytes also more clearly demonstrated that sphingosine produced the characteristic morphological changes that are hallmarks of apoptosis, including substantial chromatin fragmentation and the formation of pyknotic nuclei (Fig. 9C). These results, taken together, suggest that both developing (neonatal) and terminally differentiated (adult) cardiomyocytes are susceptible to apoptosis, although possibly to different degrees and in response to different triggers.

\section{Discussion}

This study provides the first evidence that TNF $\alpha$ and its sphingolipid second messenger molecules, including ceramide, sphingosine, and sphingosine-1-phosphate, can induce apoptosis in cardiomyocytes. Moreover, the resulting cardiomyocyte cell death is not associated with appreciable necrosis as evidenced not only by cell viability assays but also by the preponderance of apoptotic-like nuclei in the single cell gel electrophoresis (comet) assay and the presence of pyknotic nuclear fragmentation patterns characteristic of apoptosis.

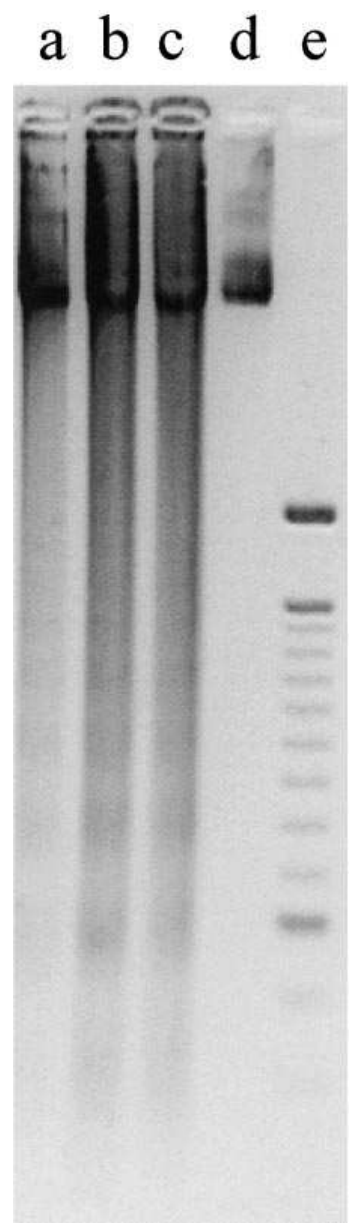

Figure 8. Oligonucleosomal DNA laddering of apoptotic rat cardiomyocytes. Neonatal cardiomyocytes were cultured for $18 \mathrm{~h}$ either in control conditions (DMEM/F12 with $10 \%$ FCS) or in the presence of $10 \mu \mathrm{mol} /$ liter sphingolipid. Total DNA was then extracted (see Methods) and fractionated on agarose $(1 \%)$ gels. Lanes $a-d$ represent electrophoresed DNA extracted from neonatal cardiomyocytes treated either with $\mathrm{C} 2 \mathrm{ce}$ ramide (lane $a$ ), sphingosine-1-phosphate (lane $b$ ), sphingosine (lane $c$ ), or control (lane $d$ ). On the right (lane $e$ ) is a 100-bp ladder.

Apoptosis and programmed cell death are often inappropriately equated with necrotic cell death. However, important distinctions can and must be made, since apoptosis and necrosis have different consequences and they present distinct histopathological features in the clinical setting. Some widely used techniques for assessing apoptosis have been criticized for their inabilities to distinguish apoptotic cells from the DNA fragmentation associated with necrosis unless other criteria are applied (44). Neither nick-end labeling nor flow cytometry can differentiate the double-strand breaks commonly associated with apoptotic cell death from the more random breaks characteristic of necrosis. The presence of oligonucleosomal DNA ladders is often used to identify double-stranded DNA breaks. However, according to Collins et al. (44), evidence of DNA laddering is not a definitive hallmark of apoptosis and should not be used as the sole criterion for apoptosis, since internucleosomal fragmentation can occur as a result of necrosis and many nuclei must be caught in synchronous fragmentation patterns to get a result. Using a variety of standard techniques and a newly developed technique for assessing DNA damage in nuclei, the comet assay, we have demonstrated the induction of apoptosis in cardiomyocytes.

The observation that $\mathrm{TNF} \alpha$ is a trigger for apoptosis in the heart suggests that the cardiotoxicity of TNF $\alpha$ observed in a variety of clinical conditions, including heart disease and sepsis, are not only due to TNF $\alpha$ 's acute negative inotropic effects (23), but may also be complicated by TNF $\alpha$-induced cell death 

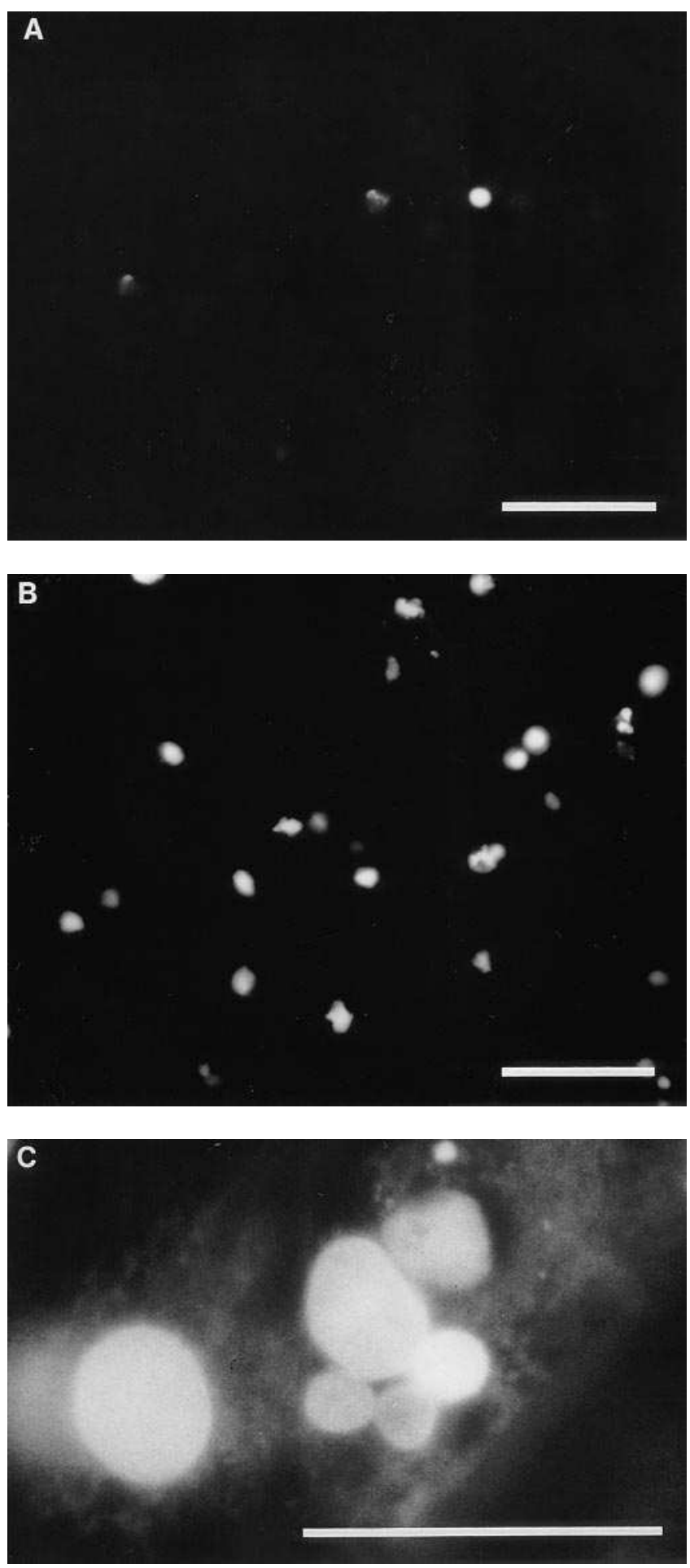

Figure 9. Apoptosis in neonatal rat cardiomyocytes. (A) TUNEL staining of untreated neonatal rat cardiomyocytes cultured for $2 \mathrm{~d}$ in DMEM/F12 with $10 \%$ FCS, showing only an occasional TUNELpositive nucleus. $(B)$ TUNEL staining of the same preparation of neonatal cells shown in $A$, but treated for $18 \mathrm{~h}$ in culture with 10 $\mu \mathrm{mol} /$ liter sphingosine. $(C)$ Ethidium bromide-stained neonatal cardiomyocytes treated with $10 \mu \mathrm{mol} /$ liter sphingosine for $18 \mathrm{~h}$. Note the crenated apoptotic cell with a very prominent pyknotic nucleus. Nonapoptotic cells appear larger and their nuclei are also larger with no evidence of DNA condensation or pyknotic apoptotic bodies. Bar represents $50 \mu \mathrm{m}$. by apoptosis. The levels of TNF $\alpha$ capable of producing apoptosis in our cultured rat cardiomyocytes are within the range found in serum of patients experiencing severe acute myocardial infarction $(16,45)$, suggesting that $\mathrm{TNF} \alpha$ may contribute to cell death by apoptosis during ischemia. It has been shown that apoptosis occurs in experimental models of ischemia/ reperfusion injury $(5,6,13)$ and, importantly, that apoptosis is a feature of human ischemic myocardial damage $(7,8)$. Moreover, it has recently been shown that apoptosis rather than necrosis determines the size of myocardial infarcts (10). Since cardiac cells themselves may produce $\operatorname{TNF} \alpha(21,22)$, local concentrations of the cytokine are expected to be higher than reported serum values, complicating our ability to estimate the extent of apoptosis that may be caused by TNF $\alpha$ during acute ischemia, heart failure, or other conditions in which TNF $\alpha$ may play a role in cardiac cell death. Since the true concentration of TNF $\alpha$ in heart tissue is unknown, one cannot know exactly the extent of $\mathrm{TNF} \alpha$-induced apoptosis. Importantly, the data in Fig. 4 also demonstrate that appreciable apoptosis in rat cardiomyocytes does not occur unless the concentration of $\mathrm{TNF} \alpha$ is in the nmol/liter range. This is in the range that just exceeds the $K_{\mathrm{d}}$ for TNF $\alpha$ binding to type I TNF $\alpha$ receptors ( $\sim 500 \mathrm{pmol} /$ liter) (25), suggesting that TNF $\alpha$-induced apoptosis is mediated by the TNF $\alpha$ receptors present on rat cardiomyocytes (23) and that apoptosis is unlikely to occur in the heart unless the $K_{\mathrm{d}}$ for the receptor is approached. Since normal human serum TNF $\alpha$ levels $(1.2 \mathrm{pg} / \mathrm{ml}$ or $70 \mathrm{pmol} /$ liter, reference 46) are far below this value, our data predict that apoptosis in the human heart would not occur in the absence of pathology and then only if the pathology is severe enough to raise local TNF $\alpha$ levels to approximate the $K_{\mathrm{d}}$ for its receptor $(8.5 \mathrm{pg} / \mathrm{ml}$ or $500 \mathrm{pmol} /$ liter $)$.

Significantly, receptor-specific anti-sTNFRI antibodies induced appreciable apoptosis in cardiomyocytes (Table III). These findings strongly implicate the type I p60 receptor in mediating $\mathrm{TNF} \alpha$-triggered apoptosis and are similar to observations made by others in which anti-TNFRI antibodies were shown to induce apoptosis $(47,48)$. It is possible that antibody cross-linking of the trimeric receptor activates the signal transduction cascade and accounts for the ability of anti-TNFRI antibodies to mimic $\mathrm{TNF} \alpha$ action.

Data presented here demonstrate that $\mathrm{TNF} \alpha$ activates the sphingomyelin signal transduction pathway, resulting in the production of the intracellular signaling molecule, sphingosine. Since sphingosine is a very effective inducer of apoptosis in cardiomyocytes, it is possible that TNF $\alpha$ 's ability to trigger apoptosis may result from $\mathrm{TNF} \alpha$-induced sphingosine production, similar to the finding that TNF $\alpha$-induced sphingosine production is responsible for apoptosis in HL-60 cells (20). Significantly, we have demonstrated that the TNFRI is the predominant receptor for TNF $\alpha$ in adult rat cardiomyocytes (23). Since it is well established that the TNFRI is the receptor linked to membrane-bound sphingomyelinase (26) and to sphingosine production (49), we speculate that TNF $\alpha$-induced apoptosis may be mediated by the TNFRI coupled to the sphingomyelin signal transduction cascade.

The mechanism of sphingosine-induced apoptosis has not yet been determined. One possibility is that sphingosine downregulates the expression of the cell death repressor, bcl-2, as it does in other cells (50). Since protein kinase C (PKC) may protect cells from apoptotic cell death $(18,51,52)$ and since sphingosine is a potent inhibitor of PKC (53), it is also possible 
that sphingosine could promote apoptosis through PKC inhibition, possibly by changing the level of bcl-2 phosphorylation $(51,52)$. It is curious that while $\mathrm{TNF} \alpha$ triggered apoptosis in adult cardiomyocytes, apoptosis could not be detected in the $\mathrm{TNF} \alpha$-treated neonatal cells. In experiments employing reverse transcriptase PCR (see Methods), we have determined that, in contrast with adult rat cardiomyocytes, neonatal cardiomyocytes in culture do not possess detectable transcript levels for the TNFRI (data not shown). This relative absence of receptor in neonatal cells can account for the observed lack of responsiveness to $\mathrm{TNF} \alpha$.

The surprising ease with which adult cardiomyocytes can be driven into apoptosis by sphingolipids and TNF $\alpha$ may be due to the presence of a preexisting death program that can be readily activated with the appropriate trigger. Apoptosis is often equated with programmed cell death and as such can also be distinguished from necrosis in that it is critically dependent upon the expression of the bcl family of protooncogenes, including bcl-2 itself, which normally protects cells from apoptotic triggers $(54,55)$. Low bcl-2 expression has been reported in adult rat and chicken cardiac muscle $(10,56)$. Thus it is possible that cardiac muscle is not well protected from apoptotic triggers. This may explain, in part, why cardiomyocytes are readily driven into apoptosis by physiologically relevant triggers of the death program, such as TNF $\alpha$ and sphingolipid second messengers.

The present study suggests that cardiac cells could be driven into apoptosis by other triggers, such as infection, injury, or hypoxia. In contrast to necrosis, apoptotic cells do not trigger a generalized immune response, nor do apoptotic cells release harmful cytoplasmic contents (e.g., lytic enzymes, potassium) that would have adverse effects on neighboring cells. Because of this "good neighbor policy," cardiac apoptosis may be an effective suicide mechanism that limits the site of injury by preventing damaged cells from injuring neighboring healthy cells. By comparison with necrotic cell death, apoptosis may thus be beneficial to the heart if it could act to limit the area of involvement; for example, during myocardial infarction, cardiac tumor growth, or viral infection of cardiac tissue. The recent finding that apoptosis and not necrosis determines the size of myocardial infarcts (10) is consistent with the notion that apoptosis may define and possibly limit the damaged area. The ability of heart cells to readily undergo apoptosis may also help explain the rare incidence of primary cardiac tumors (57). On the other hand, unregulated or inappropriate apoptosis of the heart could produce adverse consequences, such as the potential loss of cardiac cells resulting from $\mathrm{TNF} \alpha$-induced apoptosis that we predict to occur during severe sepsis. The ability of TNF $\alpha$ to drive adult cardiac cells into apoptosis may contribute to the cardiotoxic effects of TNF $\alpha$ that have limited its usefulness as a therapeutic agent in human cancer therapy and as an antiviral agent (58). The elucidation of cardiac apoptosis mechanisms will provide useful information that could potentially aid in the understanding and treatment of a wide variety of cardiac disorders.

\section{Acknowledgments}

Both K.A. Krown and M.T. Page contributed equally to this work. The authors thank Dr. Raymond R. Tice for his advice on the comet technique. The authors gratefully acknowledge the use of the SDSU Electron Microscope Facility and the SDSU Microchemical Core Facility.
This work was supported by the American Heart Association National Center (R.A. Sabbadini), the Muscular Dystrophy Association (R.A. Sabbadini), and the National Institutes of Health (2SO6 GM45765 to R.A. Sabbadini, and HL-25073 and HL-46345 to C.C. Glembotski).

\section{References}

1. Martin, S.J., D.R. Green, and T.G. Cotter. 1994. Dicing with death: dissecting the components of the apoptosis machinery. Trends Biol. Sci. 19:26-30.

2. Steller, H. 1995. Mechanisms and genes of cellular suicide. Science (Wash. DC). 267:1445-1449.

3. Thompson, C.B. 1995. Apoptosis in the pathogenesis and treatment of disease. Science (Wash. DC). 267:1456-1462.

4. Vaux, D.L., and A. Strasser. 1996. The molecular biology of apoptosis. Proc. Natl. Acad. Sci. USA. 93:2239-2244.

5. Gottlieb, R.A., K.O. Burleson, R.A. Kloner, B.M. Babior, and R.L. Engler. 1994. Reperfusion injury induces apoptosis in rabbit cardiomyocytes. $J$. Clin. Invest. 94:1621-1628.

6. Tanaka, M., H. Ito, S. Adachi, H. Akimoto, T. Nishikawa, T. Kasajima, F. Marumo, and M. Hiroe. 1994. Hypoxia induces apoptosis with enhanced expression of fas antigen messenger RNA in cultured neonatal rat cardiomyocytes. Circ. Res. 75:426-433.

7. Itoh, G., J. Tamura, M. Suzuki, Y. Suzuki, H. Ikeda, M. Koike, M. Nomura, T. Jie, and K. Ito. 1995. DNA fragmentation of human infarcted myocardial cells demonstrated by the nick end labeling method and DNA agarose gel electrophoresis. Am. J. Pathol. 146:1235-1331.

8. Itoh, G., T. Jie, J. Tamura, M. Suzuki, Y. Suzuki, H. Ikeda, and M. Nomura. 1996. Apoptosis and human ischemic myocardial damage, including conduction system. Basic Appl. Myol. 6:237-240.

9. James, T.N. 1994. Normal and abnormal consequences of apoptosis in the human heart from postnatal morphogenesis to paroxysmal arrhythmias. Circulation. 90:556-573.

10. Kajstura, J., W. Cheng, K. Reiss, W.A. Clark, E.H. Sonnenblick, S. Krajewski, J.C. Reed, G. Olivetti, and P. Anversa. 1996. Apoptotic and necrotic myocyte cell deaths are independent contributing variables of infarct size in rats. Lab. Invest. 74:86-107.

11. Buerke, M., T. Murohara, C. Skurk, C. Nuss, K. Tomaselli, A.M. Lefer. 1995. Cardioprotective effect of insulin-like growth factor I in myocardial ischemia followed by reperfusion. Proc. Natl. Acad. Sci. USA. 92:8031-8035.

12. Packer, M. 1995. Is tumor necrosis factor an important neurohumoral mechanism in chronic heart failure? Circulation. 92:1379-1382.

13. Umansky, S.R., O. Pisarenko, L. Serebryakova, I. Studneva, O. Tskitishvili, S. Khutzian, T. Sukhova, A. Lichtenstein, N. Ossina, and M. Kiefer. 1996. Dog cardiomyocyte death induced in vivo by ischemia and reperfusion. Basic Appl. Myol. 6:227-235.

14. Levine, B., J. Kalman, L. Mayer, H. Fillit, and M. Packer. 1990. Elevated circulating levels of tumor necrosis factor in severe chronic heart failure. N. Engl. J. Med. 323:236-241.

15. Lane, J.R., D.A. Neuman, A. Lafond-Walker, A. Herskowitz, and N.R. Rose. 1993. Role of IL-1 and tumor necrosis factor in coxsackie virus-induced autoimmune myocarditis. J. Immunol. 151:1682-1690.

16. Maury, C.P.J., and A.-M. Teppo. 1989. Circulating tumor necrosis factor- $\alpha$ (cachectin) in myocardial infarction. J. Intern. Med. 225:333-336.

17. Torre-Amione, G., S. Kapadia, C. Benedict, H. Oral, J.B. Yound, and D.L. Mann. 1996. Proinflammatory cytokine levels in patients with depressed left ventricular ejection fraction: a report from the studies of left ventricular dysfunction (SOLVD). J. Am. Coll. Cardiol. 27:1201-1206.

18. Jarvis, W.D., A.J. Turner, L.F. Povirk, R.S. Traylor, and S. Grant. 1994. Induction of apoptotic DNA fragmentation and cell death in HL-60 human promyelocytic leukemia cells by pharmacological inhibitors of protein kinase C. Cancer Res. 54:1707-1714.

19. Obeid, L.M., C.M. Linardic, L.A. Karolak, and Y.A. Hannun. 1993. Programmed cell death induced by ceramide. Science (Wash. DC). 259:17691771 .

20. Ohta, H., Y. Yatomi, E.A. Sweeney, S.I. Hakomori, and Y. Igarashi. 1994. A possible role of sphingosine in induction of apoptosis by tumor necrosis factor- $\alpha$ in human neutrophils. FEBS Lett. 355:267-270.

21. Kapadia, S., J. Lee, G. Torre-Amione, H.H. Birdsall, T.S. Ma, and D.L. Mann. 1995. Tumor necrosis factor- $\alpha$ gene and protein expression in adult feline myocardium after endotoxin administration. J. Clin. Invest. 96:1042-1052.

22. Giroir, P.B., J.W. Horton, J. White, K.L. McIntyre, and C.Q. Lin. 1994. Inhibition of tumor necrosis factor prevents myocardial dysfunction during burn shock. Am. J. Physiol. 267:H118-H124.

23. Krown, K., K. Yasui, M. Brooker, A. Dubin, C. Nguyen, G. Harris, P. McDonough, C. Glembotski, P. Palade, and R. Sabbadini. 1995. TNF $\alpha$ receptor expression in rat cardiac myocytes: TNF $\alpha$ inhibition of L-type $\mathrm{Ca}^{2}+$ current and $\mathrm{Ca}^{2}+$ transients. FEBS Lett. 376:24-30.

24. Torre-Amione, G., S. Kapadia, J. Lee, R.D. Bies, R. Lebovitz, and D.L. Mann. 1995. Expression and functional significance of tumor necrosis factor re- 
ceptors in human myocardium. Circulation. 92:1487-1493.

25. Vanderabeele, P., W. Declercq, R. Beyaert, and W. Fiers. 1995. Two tumour necrosis factor receptors: structure and function. Trends Cell. Biol. 5:392-399.

26. Yanaga, F., and S.P. Watson. 1992. Tumor necrosis factor alpha stimulates sphingomyelinase through the $55 \mathrm{kDa}$ receptor in HL-60 cells. FEBS Lett. 314:297-300.

27. Ostling, O., and J.P. Johanson. 1984. Microelectrophoretic study of radiation-induced DNA damage in individual mammalian cells. Biochem. Biophys. Res. Commun. 123:291-298.

28. Singh, N.P., M.T. McCoy, R.R. Tice, and E.L. Schneider. 1988. A simple technique for quantitation of low levels of DNA damage in individual cells. Exp. Cell Res. 175:184-191.

29. Fairbairn, D.W., P.L. Olive, and K.L. O’Neill. 1995. The comet assay: a comprehensive review. Mutat. Res. 339:37-59.

30. Olive, P.L., G. Frazer, and J. Banath. 1993. Radiation-induced apoptosis measured in TK6 human B lymphoblast cells using the comet assay. Radiat. Res. 136:130-136.

31. Olive, P.L., and J.P. Banath. 1995. Radiation-induced DNA doublestrand breaks produced in histone-depleted tumor cell nuclei measured using the neutral comet assay. Radiat. Res. 142:144-152.

32. Olive, P.L., D. Wlodek, and J.P. Banath. 1991. DNA double-strand breaks measured in individual cells subjected to gel electrophoresis. Cancer Res. 51:4671-4676.

33. Olive, P.L., R.E. Durand, J. Le Riche, I.A. Olivotto, and S.M. Jackson. 1993. Gel electrophoresis of individual cells to quantify hypoxia fraction in human breast cancers. Cancer Res. 53:733-736.

34. Olive, P.L. 1995. Detection of hypoxia by measurement of DNA damage in individual cells from spheroids and murine tumors exposed to bioreductive drugs. I. tirapazamine. Br. J. Cancer. 71:529-536.

35. Uzawa, A., G. Suzuki, Y. Nakata, M. Akashi, H. Ohyama, and A. Akanuma. 1994. Radiosensitivity of SD45RO+ memory and CD45RO native T cells in culture. Radiat. Res. 137:25-33.

36. Fairbairn, D.W., and K.L. O'Neill. 1995. Necrotic DNA degradation mimics apoptotic nucleosomal fragmentation comet tail length. In Vitro Cell. Dev. Biol. 31:171-173.

37. McDonough, P.M., and C.C. Glembotski. 1992. Induction of atrial natiuretic factor and myosin light chain-2 gene expression in cultured ventricular myocytes by electrical stimulation of contraction. J. Biol. Chem. 267:1166511668

38. McDonough, P.M., K. Yasui, R. Betto, G. Salviati, C.C. Glembotski, P.T. Palade, and R.A. Sabbadini. 1994. Control of cardiac $\mathrm{Ca}^{2+}$ levels: inhibitory actions of sphingosine on $\mathrm{Ca}^{2+}$ transients and $\mathrm{L}$-channel conductance. Circ. Res. 75:981-989.

39. Singh, N.P., R.E. Stephens, and E.L. Schneider. 1994. Modifications of alkaline microgel electrophoresis for sensitive detection of DNA damage. Int. J. Radiat. Biol. 66:23-28.

40. Arends, M.J., R.G. Morris, and A.H. Wyllie. 1990. Apoptosis. The role of the endonuclease. Am. J. Pathol. 136:593-608.

41. Sabbadini, R., W. McNutt, G. Jenkins, R. Betto, and G. Salviati. 1993. Sphingosine is endogenous to cardiac and skeletal muscle. Biochem. Biophys. Res. Commun. 193:752-758.
42. Hannun, Y.A., and L.M. Obein. 1995. Ceramide: an intracellular signal for apoptosis. Trends Biol. Sci. 2'0:72-76.

43. O’Neill, K.L., D.W. Fairbairn, and M.D. Standing. 1993. Analysis of single cell gel electrophoresis using laser-scanning microscopy. Mutat. Res. 319: 129-134.

44. Collins, R.J., B.V. Harmon, G.C. Gove, and J.F.R. Kerr. 1992. Internucleosomal DNA cleavage should not be the sole criterion for identifying apoptosis. Int. J. Radiat. Biol. 61:451-453.

45. Latini, R., M. Bianchi, E. Correale, C.A. Dinarello, G. Fantuzzi, C. Fresco, A.P. Maggoini, M. Mengozzi, S. Romano, and L. Shapiro. 1994. Cytokines in acute myocardial infarction: selective increase in circulating tumor necrosis factor, its soluble receptor, and interleukin-1 receptor antagonist. J. Cardiovasc. Pharmacol. 23:1-6.

46. Deng, M.C., M. Wiedner, M. Erren, T. Mollhoff, G. Assman, and H.H Scheld. 1995. Arterial and venous cytokine response to cardiopulmonary bypass for low risk CABG and relation to hemodynamics. Eur. J. Cardiol. 9:22-29.

47. Grell, M., G. Zimmerman, D. Hulser, K. Pfizenmaier, and P. Scheurich. 1994. TNF receptors TR60 and TR80 can mediate apoptosis via induction of distinct signal pathways. J. Immunol. 153:1963-1972.

48. Higuchi, M., and B.B. Aggarwal. 1994. Differential roles of two types of the TNF receptor in TNF-induced cytotoxicity, DNA fragmentation, and differentiation. J. Immunol. 152:4017-4025.

49. Rusakov, S.A., G.N. Filippova, M.Y. Pushkareva, V.G. Korobko, and A.V. Alesenko. 1993. The effect of tumor necrosis factor on free sphingosine content and sphingomyelinase activity in murine liver cells and nuclei. Biochem. (Russia). 58:476-482.

50. Chen, M., J. Quintans, Z. Fuks, C. Thompson, D.W. Kufe, and R.R. Weichselbaum. 1995. Suppression of bcl-2 messenger RNA production may mediate apoptosis after ionizing radiation, tumor necrosis faction alpha, and ceramide. Cancer Res. 55:991-994.

51. Haldar, S., N. Jena, and C.M. Croce. 1994. Antiapoptosis potential of bcl-2 oncogne by dephosphorylation. Biochem. Cell Biol. 72:455-462.

52. Haldar, S., N. Jena, and C.M. Croce. 1995. Inactivation of bcl-2 by phosphorylation. Proc. Natl. Acad. Sci. USA. 92:4507-4511.

53. Hannun, Y.A., C.R. Lommis, A.H. Merrill, and R.M. Bell. 1986. Sphingosine inhibition of protein kinase $\mathrm{C}$ activity and of phorbol dibutyrate binding in vitro and in human platelets. J. Biol. Chem. 261:12604-12609.

54. Reed, J.C. 1994. Bcl-2 and the regulation of programmed cell death. J. Cell Biol. 124:1-6.

55. Sedlak, T.W., Z.N. Oltvai, E. Yang, K. Wang, L.H. Boise, C.B. Thompson, and S.J. Korsmeyer. 1995. Multiple bcl-2 family members demonstrate selective dimerizations with Bax. Proc. Natl. Acad. Sci. USA. 92:7834-7838.

56. Eguchi, Y., D.L. Ewert, and Y. Tsujimoto. 1992. Isolation and characterization of the chicken bcl-2 gene: expression in a variety of tissues including lymphoid and neuronal organs in adult and embryo. Nucleic. Acids Res. 20: 4187-4192.

57. Goldstein, D.J., M.C. Oz, E.A. Rose, P.M. Fisher, and R.E. Michler. 1995. Experience with heart transplantation for cardiac tumors. J. Heart and Lung Transplant 14:382-386.

58. Sinhu, R.S., and A.P. Bollon. 1993. Tumor necrosis factor activities and cancer therapy-a perspective. Pharmacol. Ther. 57:79-128. 